AGNIESZKA FLUDA-KROKOS* - KRAKÓW

\title{
CATALOGUS LIBRORUM - BIBLIOTEKA KARMELITÓW BOSYCH W KRAKOWIE W ŚWIETLE RĘKOPIŚMIENNEGO KATALOGU Z 1702 ROKU $^{1}$
}

Biblioteki niewątpliwie stanowiły ważny element przestrzeni klasztornych. Ściśle ukierunkowane na tematykę religijną, starannie dobierane, świadczyły nie tylko o potrzebie posiadania i percepcji zgromadzonych dzieł, lecz były wyznacznikiem zamożności zgromadzenia i wykształcenia zakonników.Ponadto klasztory będące ostoją nie tylko wiary, stawały się istotnymi w ochranianiu kultury instytucjami, strzegąc za swymi murami cennych zbiorów, także bibliotecznych.

Klasztorne książnice są bogatym tematem badawczym, pozwalającym nie tylko przedstawić stan posiadania konkretnego klasztoru na podstawie zachowanych katalogów i inwentarzy oraz sposobów ich nabycia poprzez analizę kronik klasztornych i innych dokumentów życia codziennego zakonników, lecz także poprzez badania znaków proweniencyjnych znajdujących się w poszczególnych woluminach, wyciągać wnioski mówiące o tzw. życiu książki. Karol Głombiowski we wstępie do artykułu prezentującego bibliotekę franciszkanów w Nysie ${ }^{2}$ poza już wymienionymi korzyściami płynącymi z opracowywania inwentarzy bibliotecznych, wskazuje dodatkowo możliwość naświetlenia zainteresowań czytelniczych, przedstawienia charakterystyki językowej i typograficznej (oficyny i wydawcy) zbioru, porównanie stanu różnych bibliotek oraz ukazanie ich na tle kulturalnym epoki, a także poznanie praktycznego bibliotekarstwa. Ponadto inwentarze i katalogi mogą być cennym (i często jedynym) źródłem informacji o produkcji wydawniczej ${ }^{3}$.

* Agnieszka Fluda-Krokos - dr nauk humanistycznych w zakresie językoznawstwa, adiunkt w Instytucie Informacji Naukowej i Bibliotekoznawstwa Uniwersytetu Pedagogicznego im. KEN w Krakowie, e-mail: a.fluda_krokos@interia.pl

${ }^{1}$ Udostępnienie katalogu ze zbiorów biblioteki Klasztoru Karmelitów Bosych w Czernej oraz tłumaczenie z języka łacińskiego instrukcji bibliotecznej dzięki uprzejmości ś.p. o. prof. dr. hab. Benignusa Wanata (1934-2013).

${ }^{2}$ K. Głombiowski, Biblioteka franciszkanów w Nysie, w: Z dziejów ksiązki na Śląsku, red. B. Kocowski, M. Burbianka, K. Głombiowski, Wrocław 1955, s. 77-146.

${ }^{3}$ Tamże, s. 81-82. 
Biblioteki klasztorne stały się tematem publikacji monograficznych, ukazujących losy librarii z kręgu różnych zakonów. Są to m.in. książka Iwony Pietrzkiewicz o krakowskich kanonikach ${ }^{4}$, Marii Pidłypczak-Majerowicz o bazylianach" Krystyny Zawadzkiej o śląskich dominikanach ${ }^{6}$, Waldemara Graczyka o karmelitach bosych w Czernej ${ }^{7}$, a także tego autora książka o księgozbiorze Wyższego Seminarium Duchownego w Płocku, napisana wspólnie z Jolantą M. Marszal$\mathrm{ska}^{8}$, która jest również autorką m.in. opracowania dziejów biblioteki cystersów w Szczyrzycu9. W ostatnich latach ukazało się także sporo artykułów naukowych poświęconych tej tematyce, z najnowszych np. Antoniego Karasia o bibliotece redemptorystów w Tuchowie ${ }^{10}$, Włodzimierza Bielaka o księgozbiorze norbertanek w Imbramowicach ${ }^{11}$, Natalii Szwiec o książnicy Lwowskiego Kolegium Jezuickiego $^{12}$, Kazimierza Łataka nt. kultury książki w klasztorze kanoników regularnych w Wolbromiu ${ }^{13}$ czy też Tomasza Gałuszki nt. badań krakowskiej librarii dominikańskiej ${ }^{14}$.

$$
* * *
$$

Catalogus librorum Conventus Immacula: Conceptionis B.V.M. F.F. Carmelitarum Discalceatorum Cracoviae. Factus. Anno Domini 1702 przedstawia zawartość biblioteki pierwszego klasztoru zakonu karmelitów bosych w Polsce ${ }^{15}$. Placówka pw. Niepokalanego Poczęcia Najświętszej Maryi Panny ${ }^{16}$ została za-

${ }^{4}$ I. Pietrzkiewicz, Biblioteka kanoników regularnych w Krakowie XV i XVI w., Kraków 2003.

${ }^{5}$ M. Pidłypczak-Majerowicz, Bazylianie w Koronie i na Litwie: szkoły i książki w działalności zakonu, Wrocław 1986.

${ }^{6}$ K. Zawadzka, Biblioteki klasztorne dominikanów na Śląsku (1239-1810), Wrocław 1999.

${ }^{7}$ W. Graczyk, Księgozbiór klasztoru-eremu karmelitów bosych w Czernej od XVII do końca XIX wieku: studium z dziejów kultury intelektualnej i duchowej, Kraków 2011.

${ }^{8}$ W. Graczyk, J.M. Marszalska, Księgi rękopiśmienne i stare druki w zbiorach Biblioteki Wyższego Seminarium Duchownego w Płocku: $z$ dziejów kultury polskich bibliotek kościelnych $w$ dawnych wiekach, Kraków 2010.

9 J.M. Marszalska, Biblioteka opactwa OO. Cystersów w Szczyrzycu do końca XIX stulecia: dziedzictwo wieków, Tarnów 2007.

${ }^{10}$ A. Karaś, Dzieje Biblioteki Prowincjalnej Redemptorystów w Tuchowie: ogólna charakterystyka księgozbioru, „FIDES - Biuletyn Bibliotek Kościelnych”, 1/2 (2010) s. 184-209.

${ }^{11}$ W. Bielak, Ksiegozbiór panien norbertanek $w$ Imbramowicach, „Archiwa, Biblioteki i Muzea Kościelne" (dalej: ABMK), 95 (2011) s. 5-10.

${ }^{12}$ N. Szwiec, Próba rekonstrukcji Biblioteki Lwowskiego Kolegium Jezuickiego (1596-1773) na podstawie znaków własnościowych, w: Libri separati, red. S. Siess-Krzyszkowski, W. Walecki, Kraków 2010, s. 41-62.

${ }^{13}$ K. Latak, Kultura książki w wolbromskim klasztorze kanoników regularnych laterańskich w czasach nowożytnych, „Echa Przeszłości”, 11 (2010) s. 69-90.

${ }^{14}$ T. Gałuszka, W przededniu powstania „studium generale”, nowe badania nad czternastowiecznym zachowanym księgozbiorem dominikanów krakowskich, „Przegląd Tomistyczny”, $16(2010)$ s. $25-42$.

${ }^{15}$ Krótka charakterystyka spisu por. Graczyk, Księgozbiór klasztoru-eremu karmelitów bosych w Czernej, s. 83-84, 90-92.

${ }^{16}$ Historia zakonu wg: Cz. Gil, Czterysta lat Karmelitów bosych w Polsce (1605-2005), w: Karmelici Bosi w Polsce: 1605-2005, red. Cz. Gil, Kraków 2005, s. 13-48; tenże, Historia Kar- 
łożona w 1605 r. dzięki staraniom biskupa przemyskiego i podkanclerzego koronnego Macieja Pstrokońskiego, który na rzecz karmelitów odkupił od Jadwigi z Dębian Padniewskiej jej majątek składający się z ogrodu, dwóch budynków i stawów, znajdujący się wówczas za bramą Mikołajską ${ }^{17}$, według współczesnej topografii Krakowa przy ul. Kopernika. Do darowizny przekazanej o. Maciejowi od św. Franciszka 3 grudnia 1605 r., cztery dni po akcie donacyjnym, wprowadzili się karmelici bosi. Drewniany kościół poświęcono niecały rok później (28 października 1606 r.). Przyjęty teren okazał się jednak zbyt podmokły, dlatego też w kilkanaście lat później dzięki darowiznom ziemskim Mikołaja z Podhorzec Wolskiego, Eufrozyny Sieniawskiej Chodkiewiczównej oraz Gaspara Mikołaja Borkowskiego, po uzyskaniu przywileju króla Władysława IV z dnia 3 maja 1633 r., przystąpiono do budowy murowanych zabudowań klasztornych wraz z kościołem na wyżej położonych, sąsiednich parcelach. Prace trwały pół wieku, zaś poświęcenie budynków miało miejsce w 1683 r. Pięć lat po odrestaurowaniu zabudowań zniszczonych w czasie konfederacji barskiej, karmelici zgodnie z nakazem prymasa Polski Michała Poniatowskiego, z dnia 30 sierpnia 1787 r., zmuszeni zostali do opuszczenia budynków klasztornych i przekazania ich na rzecz szpitala św. Łazarza. Zakonnicy przeniesieni zostali do drugiej swojej krakowskiej placówki pod wezwaniem św. Michała i św. Józefa, założonej w roku 1618, mieszczącej się w budynkach przy obecnych ul. Poselskiej i Senackiej. Jednak i tutaj nie przebywali długo. W 1797 r. władze austriackie odebrały zakonowi dobra, zaś zakonnicy przenieśli się do klasztoru-eremu w Czernej. W budynkach poklasztornych umieszczono sąd oraz więzienie, a w 1954 r. przekazano je $\mathrm{Mu}-$ zeum Archeologicznemu.

Po kasacie zakonu, księgozbiór trafił do biblioteki kapitulnej oraz biblioteki zakonu misjonarzy w Krakowie. Po wielu latach, w 1963 r. odzyskano jedynie ok. 700 woluminów z Wawelu ${ }^{18}$ - bardzo zaniedbanych i zniszczonych. Przechowywane w niewłaściwych warunkach, uległy częściowo tak ogromnej degradacji, że nie nadawały się do konserwacji i naprawy. W przypadkach, gdy było to możliwe, pozostawiono jedynie karty tytułowe, resztę paląc. Obecnie $190^{19}$ ocalonych woluminów z bogatej biblioteki zakonników z klasztoru pw. NMP znajduje się w bibliotece klasztornej w Czernej.

melu Terezjańskiego, Kraków 2002; B. Wanat, Wkład i zastugi włoskich karmelitów bosych w powstanie prowincji Ducha Świętego w Polsce w 1. połowie XVII wieku, „Analecta Cracoviensia”, 27 (1995) s. 637-651; tenże, Zakon Karmelitów Bosych w Polsce: klasztory karmelitów i karmelitanek bosych 1605-1975, Kraków 1979, s. 103-108; tenże, 400 lat fundacji Zakonu Karmelitów Bosych w Krakowie i jego rozwój w 1. połowie XVII wieku w Polsce, w: Cztery wieki Karmelitów Bosych w Polsce (1605-2005), red. A. Ruszała, Kraków 2005, s. 39-54; oraz Cz. Gil, Karmelici Bosi, w: Encyklopedia katolicka, t. 8, red. A. Szostek, Lublin 2000, kol. 814-819.

${ }^{17}$ Brama Mikołajska (brama św. Mikołaja) była jedną z ośmiu istniejących wówczas bram obronnych miasta Krakowa. Wzniesiona w roku 1312, rozebrana pięć wieków później - w 1812 r.

${ }^{18}$ Część odzyskanych zbiorów pochodziła także ze skasowanego w 1797 r. klasztoru karmelitów bosych św. Michała i Józefa w Krakowie.

${ }^{19}$ Graczyk, Księgozbiór klasztoru-eremu karmelitów bosych w Czernej, s. 91. 
Inwentarz wymieniony został w kilku publikacjach, gdzie pojawia się wzmiankowany á propos zbiorów czerneńskich, jest jednym z nielicznych dokumentów archiwalnych pozostałych po klasztorze pw. Niepokalanego Poczęcia NMP, który pozwala na choćby częściowe jego zrekonstruowanie i przedstawienie funkcjonowania. W 1965 r. wspomina o nim oraz o losach części jego zbiorów Józef Długosz $^{20}$. Z kolei Jolanta M. Marszalska, pisząc o metodyce sporządzania katalogów bibliotecznych oraz strukturze treściowej księgozbiorów karmelickich, wymienia prezentowany katalog $\mathrm{w}$ gronie typowych spisów tego rodzaju, charakteryzujących się starannością i poprawnością, zgodną z obowiązującymi wówczas zasadami $^{21}$. Ta sama autorka, badając proweniencje zbiorów czerneńskich ${ }^{22}$, zwróciła uwagę na trzy wpisy potwierdzające przynależność części obecnych zbiorów do klasztoru pw. Niepokalanego Poczęcia NMP. Są to: (1) Conventus Novitatiatus ${ }^{23}$ Conceptionis Immaculatae Fratrum Carmelitarum Discalceatorum Cracoviensis, (2) Conventus Novitiatus Cracoviensis Carmelitarum Discalceatorum oraz (3) Conventus Cracoviensis Carmelitarum Discalceatorum Immaculatae Conceptionis Beatae Virginis Mariae.

Prezentowany spis biblioteki klasztornej znajduje się w Archiwum Karmelitów w Czernej24, liczy 61 kart (32-93) i zawiera wykaz książek zgromadzonych w 1702 roku w bibliotece klasztornej, będący częścią inwentarza dóbr klasztornych zatytułowanego Liber bonorum Conventus Novitiatus Cracoviensis Immaculate Conceptionis B.V. Mariae Anno Dñi 1702 sub Prioratu R. P. Cypriani à Jesu Maria Conscriptus ${ }^{25}$, sporządzonego za czasów przeoratu Cypriana od Jezusa Maryi ${ }^{26}$.

Blok o wymiarach $195 \times 290 \mathrm{~mm}$ i grubości $30 \mathrm{~mm}$ oprawiony jest w jasną skórę, ozdobioną prostymi, skromnymi geometrycznymi tłoczeniami, całość oprawy została jednak uszkodzona przez szkodniki i nieodpowiednie warunki przechowywania. Spisy sporządzone są przez jedną osobę, kaligraficznym, zazwyczaj czytelnym pismem.

Zawartość księgozbioru została zestawiona w 20 działach tematycznych ${ }^{27}$. Inwentarz nie zawiera jednak żadnych adnotacji topograficznych, mówiących o rozmieszczeniu ksiąg w bibliotece, dlatego też niemożliwym jest omówienie

${ }^{20}$ J. Długosz, Biblioteka Klasztoru oo. Karmelitów Bosych w Czernej, ABMK, 11 (1965) s. 112.

${ }^{21}$ J.M. Marszalska, Inwentarze ksiag biblioteki karmelitów bosych $w$ Czernej jako przejaw systematyzacji zbiorów klasztornych w XVIII i XIX wieku, ABMK, 89 (2008) s. 267.

${ }^{22}$ Taż, Zapisy własnościowe w księgozbiorze starych druków Karmelitów Bosych w Czernej i ich historyczne znaczenie w kulturze duchowej i intelektualnej zakonu, w: Cztery wieki Karmelitów Bosych w Polsce (1605-2005), red. A. Ruszała, Kraków 2005, s. 261-280.

${ }^{23}$ Klasztor pw. Niepokalanego Poczęcia NMP był także nowicjatem dla polskiej i litewskiej prowincji karmelitów powstałej w $1617 \mathrm{r}$.

${ }^{24}$ Zespół: Arch[iwum] Niep[okalanego] Pocz[ęcia] w Kr[akowie], Sygn. ANPK 7.

${ }^{25} \mathrm{Na}$ rękopis składają się 94 karty, w tym trzy niezapisane.

${ }^{26}$ Józef Stefanowicz, 37. przeor klasztoru. B. Wanat, Zakon Karmelitów Bosych w Polsce: klasztory karmelitów i karmelitanek bosych 1605-1975, Kraków 1979, s. 142.

${ }^{27}$ Problem nazewnictwa działów w bibliotekach klasztornych i związaną z tym dowolnością por.: H.W. Wyczawski, Kościelne zbiory biblioteczne, w: Dzieje teologii katolickiej w Polsce, t. 2, cz. 1, Lublin 1975, s. 541 (tam również bogata bibliografia tematyczna). 
sposobu ich przechowywania. Niewątpliwie jednak zbiory ułożone były w działach, zgodnie ze sporządzonym spisem. Kolejno były to: Sacra scriptura, Sancti patres, Commentatores, Theologi scholastici, Theologi morales, Spirituales, Concionatores, Controversitae, Iuris \& Civiles, Philosophi, Historici Sacri, Historici Profani, Oratores, Poetae, Libri Humanitatis, Libri Quodlibetici, Medici, Libri Polonici, Libri Hispanici, Libri Italici.

Pewne światło na przechowywanie księgozbioru, a także na kulturę książki w zakonach rzuca ogólna instrukcja dla bibliotek klasztornych karmelitów zamieszczona w Instructiones Fratrum Discalceatorum Congregationis S. Eliae Ordinis Beatissimae Virginis Mariae de Monte Carmelo (Rzym: Ludouici Grignani, 1635, s. 131-135). Dowiadujemy się z niej m.in., że biblioteka powinna gromadzić książki zachęcające do mądrości oraz mieć katalog, w którym będą spisane wszystkie tytuły, przydzielone do konkretnych działów, zaś regały i szafy ${ }^{28}$, gdzie będą one przechowywane, winny być oznaczone literami poszczególnych działów. Ponadto w bibliotece powinien znaleźć się wykaz książek zakazanych, a wydawnictwa tego typu przechowywać należy w zamkniętej szafie. Dla książek wypożyczonych powinien być prowadzony oddzielny spis oraz przygotowane rewersy wypożyczeń, a wszelkie powstałe z winy korzystającego braki należy szybko uzupełniać. Za wydawanie woluminów odpowiedzialna ma być jedna osoba, która nie może nikogo wpuszczać do magazynu. Zgodnie z instrukcją każdy tom należy oznaczyć znakiem proweniencyjnym (pieczątką lub pismem). Nakazuje ona także zapewnić dla czytelników miejsce, w którym będą mogli spokojnie skorzystać z wypożyczonych książek, ze stołami i krzesłami, a także kartki i atrament. Bibliotekarz powinien dbać o czystość i ład w bibliotece, zaś zbiory szczególnie cenne winny być przechowywane w specjalnej szafie. Na zakończenie autor napominał o obowiązku pomnażania zbiorów nie tylko o dzieła autorów historycznych, ale i współczesnych, jednak przy zachowaniu pewnej skromności. Zakładając zatem wypełnianie tej instrukcji, przyjąć należy, że biblioteka składała się z miejsc do lektury, magazynu, w którym książki były ułożone w działach (przechowywane w szafach lub na regałach), dwóch szaf specjalnych: z książkami zakazanymi oraz zbiorami cennymi ${ }^{29}$.

W sporządzonym spisie opisy w działach ułożone są alfabetycznie, przy czym po kolejnych częściach (po każdej literze) pozostawiono miejsce na dopisanie nabytków bibliotecznych. W sześciu kolumnach, na które podzielono karty, zapisane zostały następujące informacje: author, folium, editio, typogr[aphus], annus oraz poza tabelą exemp[larus]. W kolumnie, która zgodnie z nagłówkiem powin-

${ }^{28} \mathrm{Na}$ temat armariów - szaf do przechowywania ksiąg - por.: R. Werszler, Rola armarii w kulturze i dziejach ksiażki, w: Regionalne dziedzictwo kulturowe jako baza dla ksztattowania tożsamości lokalnych, red. S. Kowalska, s. 168-198; o wyposażeniu bibliotek historycznych także: M. Przywecka-Samecka, Z dziejów najstarszych pomieszczeń w Polsce. Biblioteka Kapitulna w Gnieźnie, „Zeszyty Naukowe Uniwersytetu Wrocławskiego. Seria A.” nr 38, „Bibliotekoznawstwo", nr 3, Wrocław 1962, s. 3-27.

${ }^{29}$ Dla dodatkowego zabezpieczenia tych ostatnich szafa była zamykana na klucz zdeponowany w Archiwum Konwentualnym, w tzw. skrzyni trzech kluczy (arca trium clavum), ten zaś wydawany tylko w obecności trzech osób - przełożonego i dwóch dyskretów. 
na zawierać informacje o autorze publikacji, umieszczono ponadto dane mówiące o tytule, jednak są to zapisy skrótowe i niedokładne, często sporządzane według pomysłu autora spisu. Na przykład w dziale komentarzy do pism świętych znajduje się zapis „Pauli Scherlogi in Cant.”, co zapewne jest opisem dzieła autora Cogitationes in Salomonis canticorum canticum ex triplici vestigatione humana, sacra, didactica wydanego trzykrotnie $(1633,1637,1640)$ w Lyonie, zaś dwa zapisy inwentarzowe wskazują na obecność w zbiorze dwóch ostatnich edycji. Podobnie lapidarny zapis w dziale Theologi morales: Vincentij Candidi to Proedicatorum... Illustriorum disquisitionum moralium, tomi duo : quibus omnes casus conscientice maximè practicabiles explicantur, ex sacris canonibus et probatis doctorum sententijs, ad instructionem confessariorum, et poenitentium wydany w Lyonie w 1638 r. I przykład trzeci z działu Spirituales, w którym m.in. zapis: Menologium Carmelitanum, co w rzeczywistości jest dziełem Pietro Toma Saraciniego Menologium Carmelitarum, in duas distributum partes : altera memoranda continet acta divorum quos... vetustus eremitarum ordo B. V. Mariae de Monte Carmeli... annue colit; altera antiquata quaedam, sed, auspice Deo, resumenda ejusdem instituti festa... z roku 1627, wydanego w oficynie Clemente Ferroniego w Bolonii. Inwentarz, pomimo takich skróconych opisów, dzięki przejrzystemu układowi w kolumnach i jednolitemu prowadzeniu zapisów, jest czytelny.

Spisujący używał nie tylko skrótów w rubryce autorskiej, lecz także w przypadku miejsca wydania, np. Mogunt. jako Moguncja, i wydawcy, np. Offic. Plantiniana jako oficyna Plantina. W przypadku wydawcy brak również jednolitości w zapisach - w niektórych opisach pojawia się zapis in officini lub apud i nazwa wydawcy, w innych zaś jednowyrazowe określenie, np. Andreoviensis jako krakowska oficyna Mateusza Andrzejowczyka, Hierati na określenie oficyny Antona Hierata w Kolonii lub Typo. Societ. Jesu jako oficyna wileńska zakonu jezuitów. Ponadto bardzo często autor stosuje ogólnie przyjęte określenia powtórzenia i skróty, np. eiusdem dla autora, ibidem lub ibid. dla miejsca wydania, apud eundem dla wydawcy i eodem dla daty ${ }^{30}$.

Z obliczeń wynika, że w inwentarzu zanotowano 1768 opisów książek w ok. 2150 woluminach. Biblioteka posiadała więcej niż jeden egzemplarz 146 publikacji, przy czym 21 z nich powyżej pięciu egzemplarzy. Najwyższą ich liczbę odnotowano m.in. w przypadku dzieła Philippo a Sanctissima Trinitate Maria sicut aurora consurgens, sive Tractatus de B. Mariae Virginis Deiparae immaculata Conceptione ${ }^{31}$ (Lugduni: Anton Jullieron, 1667) - 9 egz., dzieła Tomasza od Pana Jezusa Orationis mentalis via brevis et plana ${ }^{32}$ (Kraków: Franciszek Cezary, 1626) - 13 egz., Jana od Jezusa i Maryi Instructio novitiorum ${ }^{33}$ (Rzym: Carol Vulliet, 1605) - 13 egz., tegoż Schola Orationis, Contemplationis et Mortificationis passionum ${ }^{34}$ (Poznań: Jan Volrab, 1623) - 20 egz. Wymienione przykładowe publikacje były podstawowymi podręcznikami formacyjnymi.

${ }^{30}$ Tę samą zasadę zapisu J.M. Marszalska wskazała w inwentarzu biblioteki klasztornej w Czernej z roku 1718. Por. Marszalska, Inwentarze ksiag biblioteki karmelitów bosych w Czernej, s. 267.

${ }^{31}$ Zapis: Tractatus de Immac. Concept B.M.V.

${ }^{32}$ Zapis: Ejusdem Via brevis Oradnis Mentalis.

${ }^{33}$ Zapis: Instructio Novitiorum.

${ }^{34}$ Zapis: Schola Oradnis ibid. de Cultu Reginae Cal. 
Jak wspomniano, książki zostały spisane w układzie działowym. Zawartość liczbową poszczególnych części księgozbioru przedstawia poniższy wykres:

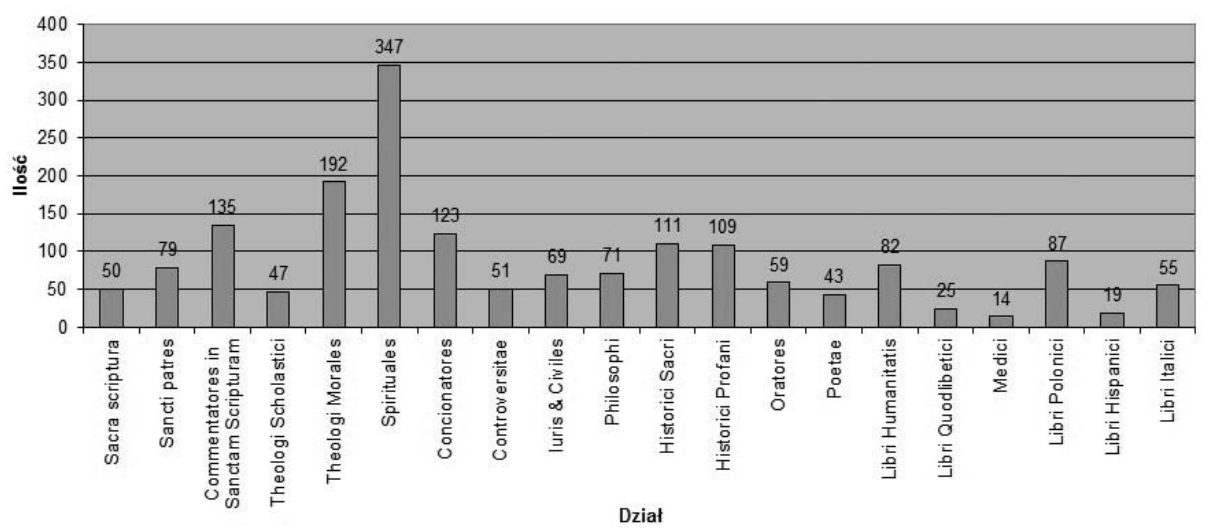

Wykres 1. Zawartość poszczególnych działów/ The contents of the individual sections Źródło: obliczenia własne.

Największy pod względem zawartości jest dział Spirituales, czyli książek poruszających tematykę kształtowania i rozwoju duchowego. Biorąc pod uwagę fakt, że klasztor pw. NMP pełnił również funkcję nowicjatu, czyli jednostki formacyjnej dla przyszłych zakonników, nie dziwi przewaga tego działu nad innymi. Powyżej 100 pozycji zapisano także w działach Historici profani (historycy świeccy) - 109, Historici sacri (historycy święci) - 111, Concionatores (kaznodziejstwo) - 123, Commentatores in sanctam scripturam (komentarze do pism świętych) - 135, Theologi morales (teologia moralna) - 192. Obecność dużej liczby publikacji dotyczących kaznodziejstwa, historii, komentarzy do pism świętych oraz dzieł teologicznych związana była zapewne również ze szczególną funkcją edukacyjną przypisaną klasztorowi. Z kolei obecność działu Oratores wraz z wymienionym już Concionatores tworzyły całość niezbędną do nauczania i nauki sztuki kaznodziejskiej.

Biorąc pod uwagę nazwy sekcji, w które pogrupowane były książki w bibliotece klasztoru za Bramą Mikołajską, warto porównać je z formami kształcenia i wychowania stosowanymi w kręgu karmelitańskim w Polsce. Kraków, w którym jednocześnie funkcjonowały dwa klasztory karmelitów bosych (pw. Niepokalanego Poczęcia NMP i pw. św. Michała i Józefa), był jednym z najważniejszych ośrodków kształcenia przyszłych zakonników ${ }^{35}$. Placówki krakowskie przyjęły następujący podział obowiązków edukacyjnych - starszy klasztor (NMP) spełniał funkcję nowicjatu, młodszy - domu studiów ${ }^{36}$. Czesław Gil w przywołanym już

${ }^{35}$ Poza tym nowicjaty istniały jeszcze w: Przemyślu, Wiśniczu Nowym, Wilnie, Poznaniu, Wiśniowcu i Głębokiem. Gil, Czterysta, s. 20.

${ }^{36}$ Tamże. 
opracowaniu ${ }^{37}$ wskazuje, że przedmiotami obowiązkowymi w nowicjacie była filozofia, teologia dogmatyczna (scholastyczna), teologia moralna oraz studiowanie Pisma Świętego. Ponadto każdy z nowicjuszy miał także swojego opiekuna, czuwającego nad jego rozwojem duchowym. Zajęcia te, a także rozprawy naukowe i podręczniki autorstwa wykładowców nowicjatu i studiów ${ }^{38}$, dotyczące teologii kontrowersyjnej, teologii życia wewnętrznego oraz mariologii, wskazują jednoznacznie na praktykę gromadzenia w bibliotece klasztoru św. Michała i Józefa druków zgodnych z zapotrzebowaniem i prowadzoną działalnością formacyjną. Tym samym wypełniano jeden z punktów instrukcji dla bibliotekarzy książnic klasztornych karmelitów mówiący, by, gromadzić księgi do mądrości zachęcające.

Ogólnie poziom kształcenia kandydatów na zakonników i samych braci ${ }^{39}$ ocenia Cz. Gil dobrze, wskazując na zagraniczne kontakty i studia karmelitów w Rzymie i Genui, skąd także przywozili do Polski niezbędne publikacje ${ }^{40}$. Stąd też zapewne do zbiorów trafiły dzieła teologiczne wydane w oficynach włoskich (Libri Italici) i hiszpańskich (Libri Hispanici). Tym samym wskazać można trzy pewne drogi nabywania zbiorów bibliotecznych: pierwsza wynikająca z odgórnego nakazu w instrukcji, drugą były kontakty z zagranicą, trzecią donacje.

Pod względem chronologii księgozbiór był typowy dla tamtego okresu - dominowały w nim druki z wieku XVII (1164), znacznie mniej pochodziło z wieku XVI - 393 tytuły, z XV - 5, z XVIII - 2 tytuly. Przy 204 pozycjach autor spisu nie podał daty druku. Warto przyjrzeć się również miejscu wydania zgromadzonych w bibliotece klasztornej ksiąg, pamiętając przy tym o zagranicznych studiach i kontaktach zakonników. Najwięcej odnotowano publikacji wydanych w Kolonii (307) oraz Krakowie (191), następnie kolejno w: Wenecji (171), Antwerpii (140), Rzymie (84), Paryżu (74) oraz Bazylei i Moguncji (po 63). Pozostałe wymienione w spisie ośrodki typograficzne wydały od 1 do 30 tytułów, a przy 398 nie podano miejsca wydania. Dane wraz z wartością procentową przedstawia wykres $\mathrm{nr} 2$.

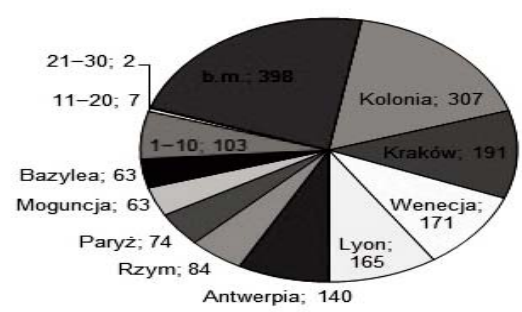

Wykres 2. Produkcja ośrodków wydawniczych w omawianym księgozbiorze/ The production of the publishing centres in the discussed book collection.

Źródto: obliczenia własne.

${ }^{37}$ Tamze, s. 19-24.

${ }^{38}$ Tamże, s. 23. Autor wymienia m.in. Mikołaja od Jezusa i Maryi, Sebastiana od Wszystkich Świętych, Ignacego od św. Jana Ewangelisty, Sebastiana od Matki Bożej i Andrzeja Brzechwę.

${ }^{39} \mathrm{O}$ edukacji duchowieństwa por. J. Flaga, Formacja i ksztatcenie duchowieństwa zakonnego w Rzeczypospolitej w XVII i XVIII wieku, Lublin 1998.

${ }^{40}$ Tamże, s. 22. 
W spisanym księgozbiorze dominują dzieła w języku łacińskim, oprócz tego kilkadziesiąt w języku polskim oraz niewielka liczba po włosku i hiszpańsku, na co wskazują odrębne działy utworzone dla tych trzech grup (Libri polonici, Libri italici, Libri hispanici).

$* * *$

Porównując inwentarz księgozbioru karmelitańskiego z pierwszego klasztoru na ziemiach polskich ze spisami ksiąg z klasztoru-eremu w Czernej ${ }^{41}$, można zauważyć wspólne, podstawowe zasady ich sporządzania, zgodne ze wspomnianą instrukcją z roku 1635 - systematyczny podział według działów ${ }^{42}$ oraz gromadzenie wydawnictw zgodnych z profilem placówki. Ponadto opisy zbudowane są w nich według tych samych haseł: autor, tytuł (lub w odwrotnej kolejności), format, typograf, rok wydania oraz ilość egzemplarzy lub tomów. Dodatkowo w spisie biblioteki nowicjatu przy kilkudziesięciu pozycjach autor zamieścił w kolumnie ilości egzemplarzy oznaczenie w postaci trzech pionowych kresek (---), np. na stronach 53 v., 57, 73. Przyjąwszy, że w przypadku wieloegzemplarzowych wydawnictw liczba egzemplarzy była oznaczana cyframi lub liczbami arabskimi, to oznaczenie przypuszczalnie można uznać bądź za znak wypożyczenia, co jednak kłóciłoby się z zapisami z instrukcji, mówiącymi o odnotowywaniu w księdze wypożyczeń oraz rewersach ${ }^{43}$, bądź za wskazanie powstałych braków, co z kolei byłoby zgodne z przepisami. Zakonnik opiekujący się księgozbiorem był bowiem zobowiązany sprawdzać, czy książki znajdują się na odpowiednim miejscu, zatem do wykonywania czynności ${ }^{44}$, które dziś nazwalibyśmy skontrum nieustającym. Dodatkowym dowodem na postawioną tezę o wskazywaniu w ten sposób braków mogą być identyczne oznaczenia znajdujące się także przy drukach o więcej niż jednym egzemplarzu (np. na s. 1). Jednak większość tego typu oznaczeń (---) znajduje się na początkowych kartach spisu.

Księgozbiór klasztoru pw. NMP w Krakowie podzielony był na 20 działów odpowiadających w większości przypadków zadaniom, jakie miał do spełnienia klasztor-nowicjat. Dla zobrazowania zawartości biblioteki kilkanaście przykładów. W dziale pierwszym - Sacra scriptura (50 wpisów) - zgromadzono wydania Pisma Świętego oraz wydawnictw pokrewnych. Wśród nich były m.in. wydanie Biblia Sacra Vulgatae Editionis (Rzym: Typographia Apostolica Vaticana, 1590), ponadto m.in. Hugo de Sancto Caro Sacrorum Bibliorum vulgatae editionis concordantiae ad recognitionem iussu... (Antwerpia: Officina Plantiniana Balthasaris Moreti, 1642), Alberti Novi Campiani Scopus Biblicus (Kraków: Łazarz Andrysowicz, 1553) oraz Psalterium. Zołtarz Dawidów ${ }^{45}$ w tłum. Walentego Wróbla (Kra-

${ }^{41}$ Marszalska, Inwentarze ksiagg biblioteki karmelitów bosych w Czernej, s. 267.

42 Tamże. Kolejno inwentarze zawierają: 1718 r. - 17 działów, 1910 r. -9 działów, 1816 r. -7 działów, 1865 r. - fragmentaryczne ujęcie działów, przełom XIX i XX w. - 10 działów (spis donacji ks. Wincentego Smoczyńskiego), 1912-1918 r. - 13 działów.

${ }^{43}$ Instructiones..., s. 133.

44 Tamże, s. 135.

${ }^{45}$ Zapis w inwentarzu: Psalterium latinopolonicum. 
ków: Wdowa Unglerowa, 1567). W dziale kolejnym - Sancti patres - wpisano 79 książek, wśród nich m.in. Jana Damasceńskiego Opera : multo quam unquam antehac auctiora, magnaque ex parte nunc de integro conuersa per D. Jacobum Bilium... Accessit locuples rerum \& verborum in his memorabilium index (Paryż 1603), św. Bazylego Opera omnia (Bazylea: Proveniana, 1540) i Conrada Gesnera Bibliotheca universalis: sive Catalogus omnium scriptorum ... in tribus linguis, Latina, Graeca [et] Hebraica (Tiguri: apud Christophorum Froschouerum, 1545). Dział trzeci - Commentatores - zawiera 135 not, m.in. Paulus Scherlogus Cogitationes in Salomonis canticorum canticum ex triplici vestigatione humana, sacra, didactica (Lugduni: Jacobus Prost, 1637); Bartholomaeus Amantius, Josephus Langius, Dominicus Nanus Mirabellius, Franciscus Tortius Novissima Polyanthea : in Libros XX Dispertita (Francofurti: Zetznerus, 1617) i św. Bernarda Thesaurvs E Monimentis D. Bernardi Clarcevallensis Abbatis primi, non perfunctorie, sed summa cura, diligentia \& fide erutus, per Nicolavm Pithoeum... (Genewa: Francisci le Preux, 1589. Z kolei w Theologi scholastici (47 wpisów) znalazły się m.in. Opuscula omnia F. Thomae de Vio Caietani Ordinis Praedicatorum Cardinalis Tituli Sancti Sixti : in tres distincta tomos : in hac vltima omnium editione diligentissimè recognita locupletissime[que] in marginibus illustrata : quorum seriem, \& quae on eis contienetus sequens index indicabit (Wenecja: Apud Franciscum de Franciscis Senensem, 1596), Jodocusa Loricha Thesaurus novus utriusque theologiae theoricae et practicae (Friburgi Brisgoiae, 1609), Otium Theologicvm Tripartitvm, Sive Amaenissimae Dispvtationes De Deo, Intelligentiis, Animabvs Separatis, Earvmqve Variis Receptaculis, trium magnorum Authorum Bartholomaei Sibyllae, Ioannis Trithemii, Alphonsi Tostati, : Singularis eruditionis variaeque lectionis plenissimae opusculis, comprehensae (Duaci : Bellerus, 1621). W innym, Theologi morales, ze 192 opisami znajdujemy, m.in. Francesco Bordoni Varice resolutiones; seu Consilia regularia; nedum Regularibus Personis, verùm etiam Proelatis Ecclesiasticis, Sacerdotibus, Iudicibus, Aduocatis, Causidicis, aliisque in utroque Foro versantibus apprimè utilia, imò \& necessaria (Wenecja: Apud Bertanos, 1641), Ioannis Sanchez Selectas disputationes de rebus in administratione Sacramentorum, praesertim Eucharistia... (Antwerpia: Petri Belleri, 1644). Z kolei Spirituales (347) zawiera m.in. Kaspra Drużbickiego Negotiatio Spiritvalis : Per varias Indvstrias Aternis Intenta Lvcris Conscripta (Kraków: In Officina Schedeliana, [1674]). Przytoczone przykłady to tylko niewielka część z 1768 wpisów. Jak już zauważono, wpisy zazwyczaj nie mają zbyt wiele wspólnego z pełnym tytułem odnotowanego dzieła, co utrudnia identyfikację książek i dopiero całościowe rozszyfrowanie zawartości inwentarza dałoby pełny obraz librarii klasztornej tego krakowskiego zgromadzenia.

Na zakończenie, przyjmując za K. Głombiowskim ${ }^{46}$ jeden z aspektów badań wynikających z inwentarzy i katalogów, obliczeniom szczegółowym poddano produkcję oficyn w dziale Libri Polonici, zawierającym 78 wpisów. Przy 72 pozycjach podano miejsce druku oraz uproszczoną nazwę drukarni. $Z$ racji na lokalizację klasztoru w Krakowie, nie dziwi obecność aż 61 druków miejscowych oficyn

\footnotetext{
${ }^{46}$ Głombiowski, Biblioteka franciszkanów w Nysie, s. 82.
} 
- m.in. Piotrkowczyków (18), Schedlów (10), Cezarych (8), Łazarza Andrysowicza (8). Poza tym odnotowano sześć publikacji poznańskich, cztery wileńskie oraz jedną lubelską. Zaznaczyć należy, że książki z rodzimych oficyn znajdują się także w innych działach, dlatego też pełny obraz mogłaby dać szczegółowa analiza całego inwentarza. Przykładowo samych druków krakowskich wpisano aż 191, a poza wymienionymi już Poznaniem, Wilnem i Lublinem, książnica posiadała także woluminy z Leszna, Warszawy, Wrocławia i Zamościa.

$* * *$

Z wstępnej analizy inwentarza biblioteki pierwszego klasztoru karmelitów bosych w Polsce, wyłania się obraz księgozbioru gromadzonego zgodnie z profilem placówki, a także według obowiązujących zakonników przepisów bibliotecznych z roku 1635. Spis sporządzony metodycznie, z podziałem na sześć elementów opisu (autor i tytuł, format, miejsce wydania, oficyna, rok wydania oraz liczba egzemplarzy), nie jest jednak pozbawiony mankamentu charakterystycznego dla tego typu rękopisów - bardzo częstego podawania autora i tytułu w formie skróconej ${ }^{47}$, popularnej, różniących się od wydrukowanych w książce. Za takim sposobem zapisu przemawiała ekonomia, zważywszy na bardzo rozbudowane tytuły druków z wieków XV-XVIII, których pełny zapis wymagałby od notującego i większej ilości czasu, i miejsca na kartach. Powodem drugim takiej notacji są także funkcjonujące $\mathrm{w}$ języku codziennym tytuły i określenia - skrótowe i umowne, np. zapis Tractatus de Immac. Concept B.M.V. był odpowiednikiem dzieła Philippo a Sanctissima Trinitate Maria sicut aurora consurgens, sive Tractatus de B. Mariae Virginis Deiparae immaculata Conceptione (Lugduni: Anton Jullieron, 1667). Owa prostota notacji, zrozumiała dla ówczesnych użytkowników librarii, w opracowaniu i edycji źródeł jest kłopotliwa i wymaga długich poszukiwań, ułatwionych jednak coraz bardziej dzięki bazom starodruków dostępnym także on-line ${ }^{48}$.

Liczne druki zagraniczne (np. Kolonia - 307, Wenecja - 171, Antwerpia 140), a także więzi zakonników odbywających studia poza Polską, wskazują na rozległe kontakty zobowiązanych do gromadzenia odpowiednich publikacji z wydawcami i księgarzami obcymi. Ponadto obecność ok. 250 druków o proweniencji polskiej jest dowodem na liczną produkcję religijną polskich drukarń.

Podział księgozbioru na 20 wymienionych działów był także typowy dla bibliotek klasztornych, gromadzących księgi o określonej tematyce. W przypadku tej konkretnej książnicy szczególną uwagę poświęcano na gromadzenie druków niezbędnych w prowadzeniu nowicjatu.

Niestety, jest to także jedna z tych bibliotek klasztornych, które nie uchroniły się przed zmianami historycznymi. Czterokrotne przenosiny zakonników pw. Niepokalanego Poczęcia Najświętszej Maryi Panny odbiły się negatywnie także na księgozbiorze. Z 1768 pozycji zapisanych w inwentarzu z 1702 r. obecnie przechowywanych w Archiwum Karmelitów Bosych w Czernej jest 190 ${ }^{49}$, co stanowi zaledwie ok. $11 \%$ całości.

${ }^{47} \mathrm{~W}$ artykule dla zobrazowania problemu w kilku przypadkach podano zapis zaczerpnięty $\mathrm{z}$ inwentarza.

${ }^{48} \mathrm{~Np}$. HBP (Heritage of the Printed Book Database) - ok. 3 mln opisów, WorldCat.org (The World's Largest Library Catalog) - 2 bln opisów (dane z 25. 01. 2014 r.).

${ }^{49}$ Graczyk, Księgozbiór klasztoru-eremu karmelitów bosych w Czernej, s. 91. 


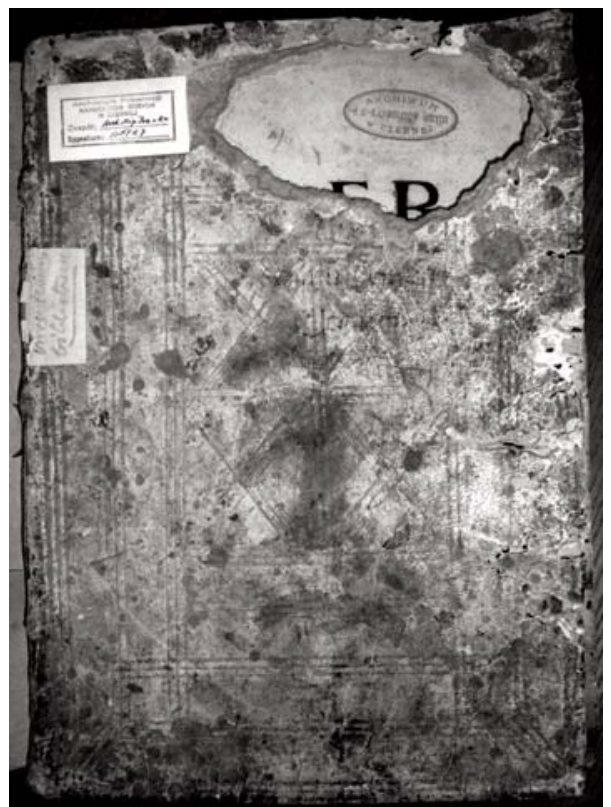

Fot. 1 Oprawa przednia boku, Catalogus librorum Conventus Immacula: Conceptionis B.V.M. F.F. Carmelitarum Discalceatorum Cracoviae. Factus. Anno Domini 1702. Fot. A. Fluda-Krokos/ The front binding of the side, Catalogus librorum Conventus Immacula... Photograph: A. Fluda-Krokos.

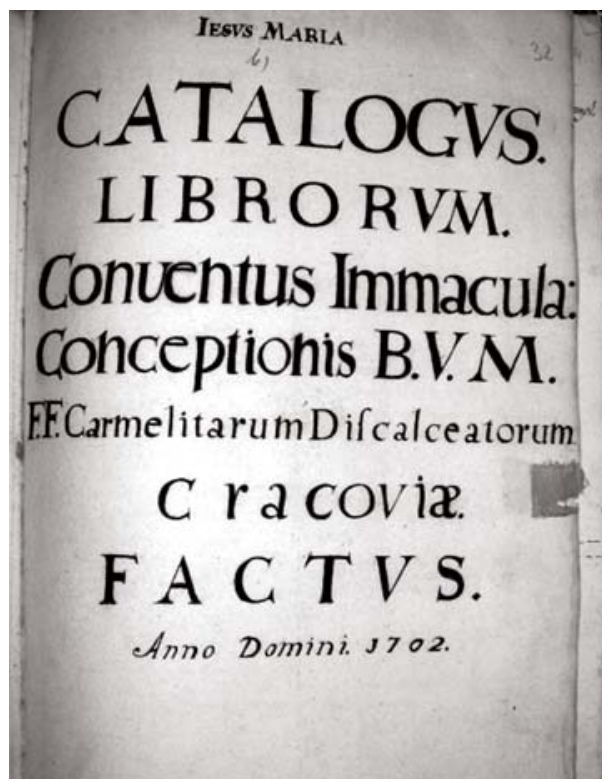

Fot. 2. Strona tytułowa inwentarza biblioteki - Liber bonorum Conventus Novitiatus Cracoviensis Immaculate Conceptionis B.V. Mariae Anno Dñi 1702 sub Prioratu R. P. Cypriani à Jesu Maria Conscriptus/ The title page of the library inventory - Liber bonorum Conventus Novitiatus Cracoviensis.... 


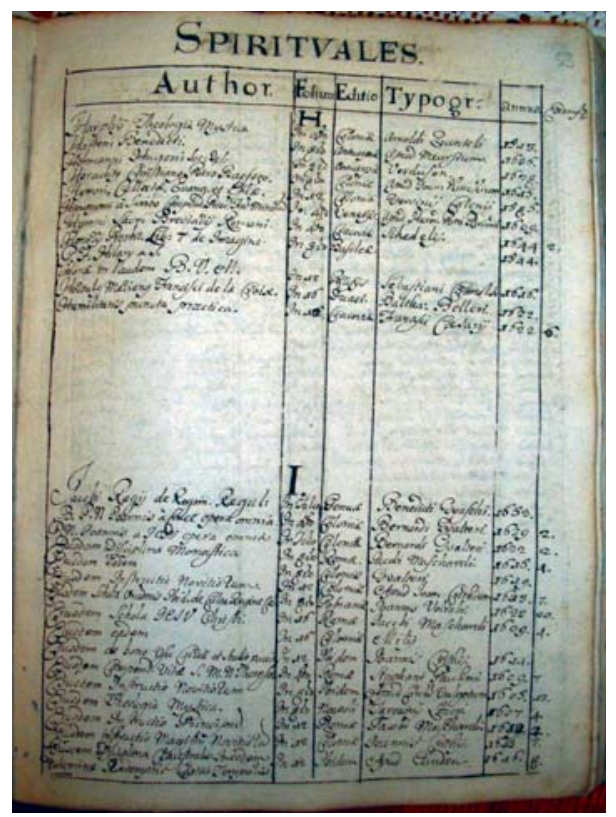

Fot. 3. Przykładowa strona inwentarza (53). Fot. A. Fluda-Krokos/ A sample page of the inventory (53)

Słowa kluczowe: biblioteka klasztorna, karmelici bosi, inwentarz biblioteczny, starodruki, Kraków

\title{
CATALOGUS LIBRORUM -THE LIBRARY OF THE DISCALCED CARMELI- TES IN CRACOW IN THE LIGHT OF THE MANUSCRIPT CATALOGUE OF 1702
}

\begin{abstract}
Summary
This paper presents a preliminary analysis of the contents of the first monastic library of the Carmelite Order in Poland. On the basis of the manuscript Catalogus librorumConventus Immacula: Conceptionis B.V.M. F.F. Carmelitarum Discalceatorum Cracoviae. Factus. Anno Domini 1702 it was discovered that the library of the monastery church devoted to the Holy Virgin Mary in Cracow was divided into 20 sections, and the most numerous ones were the Spirituales and Theologi morales sections. Calculations show that the inventory includes 1768 descriptions of books in approx. 2150 volumes. Currently, 190 survived volumes are located in the monastic library in Czerna.
\end{abstract}

Keywords: monastic library, the Discalced Carmelites, library inventory, antique books, Cracow 